\title{
Heterogeneity in Migrating Neural Crest Cells Revealed by a Monoclonal Antibody
}

\author{
M. Barbu, C. Ziller, P. M. Rong, and N. M. Le Douarin \\ Institut d'Embryologie du CNRS et du Collège de France, 94736 Nogent-sur-Marne, Cedex France
}

A monoclonal antibody, GIN1, obtained by immunization with extracts of the $14 \mathrm{~d}$ embryonic quail nodose ganglion, is described. GIN1 recognizes an antigenic determinant present in virtually. all the satellite cells of the peripheral ganglia, all Schwann cells of the peripheral nerves, and in subpopulations of sensory and autonomic neurons of embryonic and adult quails and chickens. The molecular weight of the antigen(s) revealed by GIN1 in embryonic day 12 quail dorsal root ganglion (DRG) cultures is around $80 \mathrm{kDa}$.

In the neural crest, GIN1 determinant is found as soon as the crest cells leave the neural primordium. Only a proportion $(\mathbf{2 5 \%})$ of the migrating neural crest cells carry the antigen. This demonstrates that the neural crest is composed of a heterogeneous population of cells from its early migratory stages.

Being selectively distributed on neural crest cells and its derivatives, the GIN1 determinant may be considered as a "differentiation antigen" that will be useful in further studies on cell-line scgregation during the ontogeny of the PNS.

The avian neural crest lends itself particularly well to studies of the generation of cellular diversity in the development of the vertebrate nervous system. There are several reasons for this. One is that after losing their epithelial organization, the cells of the lateral neuroepithelial ridges form a well-defined, although transient, anatomic entity. This feature, together with the accessibility of the avian embryo to experimentation throughout development, enables the neural crest to be manipulated with equal ease in ovo and in vitro. In spite of the complexity added to this developmental system by the migratory behavior displayed by crest cells at the early stages of their ontogeny, the fate and developmental potentials of the crest cells issuing from every region of the neuraxis have been precisely documented by cell-marking analysis (see Le Douarin, 1982, for a review). The neural crest, in fact, displays a strikingly large range of developmental potentialities, since it generates not only most of the PNS, but also gives rise to melanocytes, certain endocrine and paraendocrine cells, and the so-called mesectodermal mesenchyme from which the bones and dermis of the face develop. This diversity raises the problem of the mechanisms through

Received Sept. 18, 1985; revised Jan. 14, 1986; accepted Jan. 30, 1986.

This work was supported by the Centre National de la Recherche Scientifique and by grants from the Institut National de la Santé et de la Recherche Médicale, the Ministère de la Recherche et de l'Industrie, the Fondation pour la Recherche Médicale Française and the Ligue contre le Cancer, and by a Basic Research Grant 1-866 from March of Dimes Birth Defects Foundation.

We wish to thank Drs. M. A. Teillet and M. Kinutani for providing quail-chick chimeric tissues, Dr. J. Smith for helpful advice and discussion, M. Gendreau for her assistance in the culture experiments, Dr. D. Paulin for gifts of antibodies, and B. Henri, E. Bourson, and A. Le Mouël for their help in the preparation of the manuscript.

Correspondence should be addressed to Prof. N. Le Douarin, Institut d'Embryologie du CNRS et du Collège de France, 49 bis, Avenue de la Belle-Gabrielle, 94736 Nogent-sur-Marne, Cedex France.

Copyright (C) 1986 Society for Neuroscience $0270-6474 / 86 / 082215-11 \$ 02.00 / 0$ which cell lineages become segregated during neural crest cell ontogeny.

It has been well documented in recent years (see Le Douarin, 1982; Weston, 1982, for reviews) that the expression of the various phenotypes characterizing neural crest derivatives depends largely on environmental cues encountered by crest cells during their migration and in the sites where they settle. Such cues may select among the developmental capacities of the incoming crest cells in different ways: They may selectively ensure the survival of crest cell subpopulations that are already restricted ("committed") in their developmental capacities, or they may trigger, in labile ("pluripotent") cells, the expression of biochemical pathways characteristic of a particular differentiated phenotype. Consequently, it is important to ascertain the degree of commitment of neural crest cells during their developmental history from the neural primordium to their fully differentiated derivatives. This is why we have undertaken to determine the extent to which heterogeneity exists in the population of crest cells leaving the neural primordium.

A number of recent investigations (Le Douarin, 1984; Ziller et al., 1983) lead indirectly to the conclusion that certain developmental choices are already made by the time the migration process gets under way, or shortly thereafter.

In the present study, we have used monoclonal antibody (MAb) technology with the aim of detecting surface antigens on differentiated peripheral ganglion cells. We describe here one such $\mathrm{MAb}$, termed GIN1, with which, in conjunction with other cell markers, it has proved possible (1) to assess the correspondence between MAb immunoreactivity and different PNS phenotypes, and (2) to demonstrate the presence of the antigenic determinant identified by GIN 1-MAb on a subpopulation of migratory neural crest cells, thus showing a cellular heterogeneity in this embryonic primordium from these early stages onward.

\section{Materials and Methods}

Commercially obtained, outbred quail (Coturnix coturnix japonica) and white Leghorn chick (Gallus gallus) eggs were the sources of all embryos used for this investigation.

\section{Monoclonal antibody preparation}

\section{Immunization and fusion procedure}

Nodose ganglia (50-60) were removed from 14-d-old (E14) Japanese quail embryos, homogenized in $0.5 \mathrm{ml}$ of $\mathrm{Ca}^{2+}, \mathrm{Mg}^{2+}$-free PBS, and intraperitoneally (i.p.) injected into mice. Two $\mathrm{Balb} / \mathrm{C}$ female mice were so immunized 4 times by i.p. injection (days $0,7,14,21$ ) and boosted intravenously at day 22 with the same material. Three days after the boost, the mice were sacrificed and their spleens removed. Splenocytes were fused with $\mathrm{Sp} 2 / 0$ mouse myeloma (ratio 2:1) in the presence of polyethylene glycol according to the method of Köhler and Milstein (1975). Fused cells of the 2 mice were plated on 23 plates of 24 well tissue culture dishes (Nunc). 


\section{Screening for antibody production}

Undiluted hybrid supernatants were tested for secreted antibody by indirect immunofluorescence on living microcultures of dissociated nodose, sympathetic, and dorsal root ganglia (DRG) and embryonic liver and heart grown for $2 \mathrm{~d}$ as described below.

\section{Grafting procedures and quail-chick cell identification}

Specific labeling of neural crest cells was obtained through isotopic and isochronic grafting of the quail neural primordium into chick embryos either at the cephalic or brachial levels of the neuraxis. The grafting procedure has been described in detail previously (see Le Douarin, 1982).

In sections of quail-chick chimeras and in culture of chimeric nerves, the quail nuclear marker was evidenced by the staining procedure of Feulgen-Rossenbeck (1924) and by applying Hoechst stain for DNA (Franklin and Martin, 1980).

\section{Cell cultures}

\section{Cultures of peripheral ganglia and nerves}

Nodose ganglia, DRG, and sympathetic chains were dissected out from E12-E15 quails. The brachial plexus of a chick embryo in which the neural primordium of a quail had been implanted at the level of somites $17-21$ at the 24-somite stage was also used in these studies. Cell suspensions were prepared by trypsin (Difco) treatment $\left(0.1 \%\right.$ in $\mathrm{Ca}^{2+}$, $\mathrm{Mg}^{2+}$-free PBS) for $15 \mathrm{~min}$ at $37^{\circ} \mathrm{C}$ followed by gentle pipetting. The cells were washed in Dulbecco's modified Eagle's medium (DMEM; Gibco) supplemented with $10 \%$ newborn-calf serum (NCS; Gibco), centrifuged (1000 $\times \mathrm{g}, 10 \mathrm{~min})$, and resuspended in culture medium. Cells $\left(10^{4}\right)$ were plated in $35 \mathrm{~mm}$ tissue culture dishes (Nunc) containing 0.2 $\mathrm{ml}$ of medium. After $12 \mathrm{hr}$ in the incubator, the cells had attached to the substrate and fresh medium was added. The complete culture medium was DMEM supplemented with $10 \%$ NCS, antibiotics, and $30 \%$ quail embryo yolk sac extract. For antibody screening purposes, $3 \times$ $10^{3}$ cells/well were plated in Terasaki microtest plates (Falcon). Control cultures consisted of E2 quail embryonic heart cells and E9 liver cells, dissociated and plated according to the procedure described above.

All cultures were grown at $37^{\circ} \mathrm{C}$ in a humidified atmosphere of $\mathrm{CO}_{2}$ : air (5:95).

\section{Neural crest cultures}

Migrating mesencephalic neural crests were removed from 10- to 12somite quail embryos as described previously (Ziller et al., 1983). The explants (4-5/dish), together with the associated fragment of superficial ectoderm, were placed in DMEM containing $15 \%$ fetal calf serum (Gibco) and 2\% E9 chick embryo extract. The neural crest cells rapidly migrated out and spread around the ectodermal explant. Immunocytochemistry was performed $12 \mathrm{hr}$ after plating. In certain experimental series, the mesencephalic neural crests were dissociated to single cells (Ziller et al., 1983) and plated at a density of $8 \times 10^{3}$ cells $/ 35 \mathrm{~mm}$ dish.

Trunk neural crest cells were obtained from trypsin-isolated neural tubes of 20- to 25-somite quail embryos according to the technique first described by Cohen and Konigsberg (1975), using the above-described medium. Immunocytochemistry was performed $24 \mathrm{hr}$ after plating.

\section{Immunocytochemistry}

\section{Antibodies}

GIN1 was used as 1:100 and 1:500 dilutions of ascitic fluid. Rabbit antiserum against the $70 \mathrm{kDa}$ neurofilament protein (NF-70), a gift from Dr. D. Paulin, was used as detailed by Cochard and Paulin (1984). Tetanus toxin antiserum was prepared in our laboratory as described by Ziller et al. (1983).

The fluorescent dye-conjugated antibodies were fluorescein isothiocyanate-conjugated goat anti-mouse and goat anti-rabbit Ig (GAM-, GAR-FITC), and tetramethylrhodamine isothiocyanate-conjugated goat anti-mouse and goat anti-rabbit Ig (GAM-, GAR-TRITC). All were purchased from Nordic Immunology and used at a dilution of 1:50.

\section{Immunostaining with $M A b$}

The following indirect immunofluorescence techniques were applied to: 1. Serial sections $(7 \mu \mathrm{m})$ of quail and chick embryos taken at devel- opmental stages from E2 to E14. Peripheral ganglia from 5-month-old quails were also studied; the tissues were fixed either in $4 \%$ paraformaldehyde in PBS followed by embedding in PEG as described previously (Cuchard et al., 1978, 1979) or fixed in Bouin's fluid and embedded in paraffin.

2. Fresh suspensions of living cells.

3. Cells and explants in culture. In this case, the antibodies were applied either to living cells or to cells fixed with $4 \%$ paraformaldehyde in PBS.

On sections or fixed cultures, GlN1 was left to react overnight at $4^{\circ} \mathrm{C}$ The samples were then washed several times with PBS containing 5\% NCS and exposed to the second antibody for $1 \mathrm{hr}$ at room temperature

Living cells, either in culture or in suspension, were incubated for 20 min at $37^{\circ} \mathrm{C}$, with the antibody diluted in DMEM supplemented with $1 \%$ NCS and $10 \mathrm{mM}$ HEPES. Cultures were then washed in DMEM and PBS and postfixed in $100 \%$ ethanol for $30 \mathrm{~min}$ at $-20^{\circ} \mathrm{C}$. Cell suspensions $\left(2 \times 10^{4}\right.$ cells per experiment $)$ were washed by centrifugation through an NCS layer at $1000 \times g$ for $10 \mathrm{~min}$.

\section{Double-immunolabeling experiments}

In order to identify nerve cells in cultures or cell suspensions at the same time as GIN1 immunoreactivity, 2 neuronal markers were employed. Tetanus toxin binding sites (tetanus toxin was a gift from B. Bizzini, Institut Pasteur, Paris) were evidenced as described by Ziller et al. (1983), using GAR-TRITC as the second antibody, followed by GIN1 and then by GAM-FITC. The presence of ncurofilament protcin was visualized by the use of anti-NF-70 and GAR-TRITC. Fixed cultures were treated with $0.25 \%$ Triton $\mathrm{X}-100$ in PBS for $10 \mathrm{~min}$ prior to application of NF-70 antibody. The cells were then incubated successively with NF-70 antibody, GAR-TRITC, GIN1, and GAM-FITC.

The staining of cell suspensions involved, first, exposure to GIN1 and GAM-FITC and then a fixation step on slides with $100 \%$ methanol for 6 min at $-20^{\circ} \mathrm{C}$, followed by treatment with NF- 70 antibody and GARTRITC.

\section{Determination of immunoglobulin subclass}

The immunoglubulin subclass of the MAbs described was determined by using rabbit anti-mouse subclass Ig (Bionetics) in our indirect immunofluorescence assay on cell cultures. In all cases, sections, cultures, or cell suspensions were mounted in glycerol-PBS (7:3), examined by epifluorescence with a Leitz-Orthoplan microscope, and photographed on Kodak Ektachrome (400 or 800 ASA) or TRI-X film.

\section{Preliminary characterization of antigens recognized by GINI}

\section{Radiolabeling of cells}

For biosynthetic labeling, $10^{6} \mathrm{E} 12$ quail DRG cells, after culture in 35 $\mathrm{mm}$ dish for $48 \mathrm{hr}$, were preincubated at $37^{\circ} \mathrm{C}$ for $1 \mathrm{hr}$ in a methioninefree MEM (Gibco) supplemented with $10 \%$ dialyzed NCS. Then, 200 $\mu \mathrm{Ci}$ of $\mathrm{L}-{ }^{35} \mathrm{~S}-$ methionine $(800 \mathrm{Ci} / \mathrm{mmol}$, Amersham) was added per dish. After 3-4 hr of incubation, the cell layer was washed 3 times with PBS containing $10^{-2} \mathrm{M}$ L-methionine. Labeled cells were then incubated on ice for $10 \mathrm{~min}$ with gentle agitation in $200 \mu$ lof lysis buffer: $0.5 \%$ Nonidet P40 (NP40), $1 \mathrm{~mm}$ phenylmethylsulfonyl fluoride in PBS. Cells were then scraped off the dish, transferred to an Eppendorf tube, briefly vortexed, and kept on ice for a further $30 \mathrm{~min}$. Supernatants were collected after centrifuging at $1000 \times g$ for $10 \mathrm{~min}$, centrifuged once more at $15,000 \times g$ for $15 \mathrm{~min}$, and then stored at $-80^{\circ} \mathrm{C}$.

\section{Immunoprecipitation and electrophoresis of radiolabeled cell proteins}

The immunoprecipitation procedure was performed according to a modification of the technique of Charron and Mc Devitt (1980). Briefly, samples (usually $100 \mu$ lysate per MAb tested) were first precleared for 15 min at $4^{\circ} \mathrm{C}$ with $80 \mu \mathrm{l}$ Staphylococcus aureus, Cowan I strain (SaC) preparation $(10 \% \mathrm{wt} / \mathrm{vol}$ suspension in $0.5 \% \mathrm{NP} 40,0.1 \% \mathrm{BSA}, 0.4 \mathrm{M}$ $\mathrm{NaCl}, 0.1 \mathrm{M}$ Tris- $\mathrm{HCl}, \mathrm{pH} 8$ ). The resulting supernatants were precleared twice more with rabbit anti-mouse Ig serum (RAM; Nordic; $8 \mu \mathrm{l}$ of 10 $\mathrm{mg} / \mathrm{ml} \mathrm{RAM}$ incubated for $30 \mathrm{~min}$ at $4^{\circ} \mathrm{C}$ with $80 \mu \mathrm{l}$ of SaC preparation). After the third preclearance, samples were immunoprecipitated on ice for $2 \mathrm{hr}$ with $10 \mu \mathrm{l}$ of MAb ascitic fluid or an irrelevant IgM ascitic fluid, anti-MB1 (Péault et al., 1983), followed by incubation for $15 \mathrm{~min}$ at $4^{\circ} \mathrm{C}$ with the same (RAM-SaC) complex. Immunoprecipitates were 

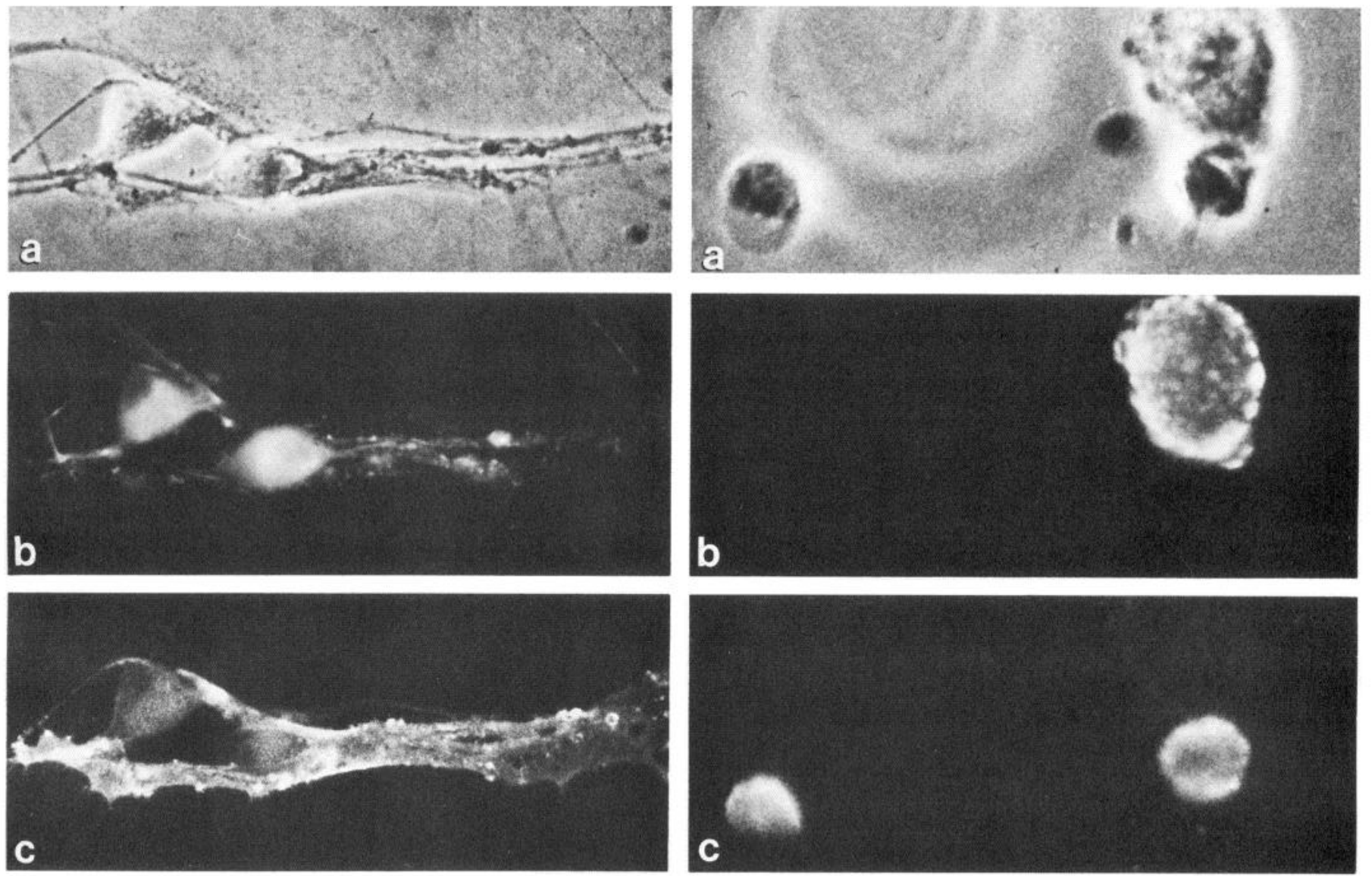

Figure 1. Left, Six-day culture of E12 quail nodose ganglion fixed with 4\% paraformaldehyde. $a$, Phase-contrast showing neurons and non-neuronal cells. $b$, Anti-NF-70 and GAR-TRITC labeling showing immunoreactive neurons. $c$, GIN1-MAb and GAM-FITC label only the glial cell. $\times 318$.

Figure 2. Right, Suspension of E15 quail nodose ganglion cells. $a$, Phase-contrast showing 1 large and 2 small cells. $b$, Tetanus toxin binding sites are revealed with a rabbit antibody against tetanus toxin and GAR-TRITC. Note that only the large cell is stained and can therefore be considered as neuronal. $c$, The 2 small non-neuronal cells are stained by GIN1. The double labeling was performed on living cells. Tetanus toxin, anti-tetanic serum, GAR-TRITC, GIN1, and GAM-FITC were applied successively. The suspension was then mounted in PBS-glycerol and observed. $\times 516$.

collected with $1 \mathrm{ml}$ of buffer $(0.5 \% \mathrm{NP} 40,0.4 \mathrm{M} \mathrm{NaCl}, 0.1 \mathrm{M}$ Tris- $\mathrm{HCl}$, $\mathrm{pH} 8$ ) and transferred to a tube containing the same buffer supplemented with $10 \%$ sucrose. Samples were washed 3 times, eluted into $25 \mu \mathrm{l}$ of sample buffer $(2.5 \%$ SDS, $5 \%$ mercaptoethanol, $10 \%$ glycerol, $0.01 \%$ bromophenol blue, $65 \mathrm{~mm}$ Tris- $\mathrm{HCl}, \mathrm{pH} 8$ ), boiled for $3 \mathrm{~min}$, and loaded. on $6.5 \%$ polyacrylamide gels (Laemmli, 1970). After running, gels were fixed, impregnated with Enlightning (New England Nuclear), dried, and placed in contact with X-ray film (Kodak) for $7-10$ days at $-70^{\circ} \mathrm{C}$.

\section{Results}

Of the 552 wells initially plated, 469 contained 1 or more hybrid colonies. Of these 469 polyclonal cultures, 100 wells showed immunoreactivity with peripheral ganglion cell cultures. Twenty that were found to react with the latter and not with liver and heart cells were subsequently cloned. Two MAbs (GIN1 and GIN2, both IgM) were selected for further examination. In this article, we describe the cellular specificity of GIN1. In its staining pattern, GIN2 showed some similarity to previously described MAbs, such as HNK1 and NC1 (Abo and Balch, 1981; Tucker et al., 1984; Vincent and Thiery, 1984), and it is only given a passing mention here. Its characteristics will be the object of detailed analysis elsewhere.

Cellular specificity of GIN1 on peripheral ganglia and nerves during the second half of embryonic life

GIN1 applied to living or fixed cultures of E12 quail nodose ganglion and DRG stained a few neurons and most non-neu- ronal cells (Fig. 1). In living cultures, membrane antibody binding sites were evenly distributed over the cell bodies and processes.

In order to discriminate more accurately between neuronal and glial immunoreactivity, we performed double labeling with NF-70 antibody or visualization of tetanus toxin binding sites and GIN1 of peripheral ganglia cell suspensions removed from E15 quails (Fig. 2). The results presented in Table 1 show that, in DRG suspensions, around $10 \%$ of the cells containing NF-

Table 1. Percentages of GIN1-positive cells in cell suspensions of various E15 quail peripheral ganglia

\begin{tabular}{lll} 
Ganglion & $\begin{array}{l}\text { Neurons } \\
\text { (anti-NF-70- } \\
\text { positive cells) }\end{array}$ & $\begin{array}{l}\text { Non-neuronal cells } \\
\text { (anti-NF-70- } \\
\text { negative cells) }\end{array}$ \\
\hline DRG & $9.5 \pm 1.7$ & $68.9 \pm 8.6$ \\
& $(n=5)$ & $\begin{array}{l}(n=5) \\
\text { Sympathetic }\end{array}$ \\
Nodose & $22.5 \pm 3.7$ & $71.2 \pm 2$ \\
$(n=3)$ & $(n=3)$ \\
& $18.1 \pm 3.6$ & $54.6 \pm 11.5$ \\
$(n=4)$ & $(n=4)$
\end{tabular}

About 200 cells were counted in each experiment. The percentages are expressed as means \pm SEM. $n=$ number of experiments. 

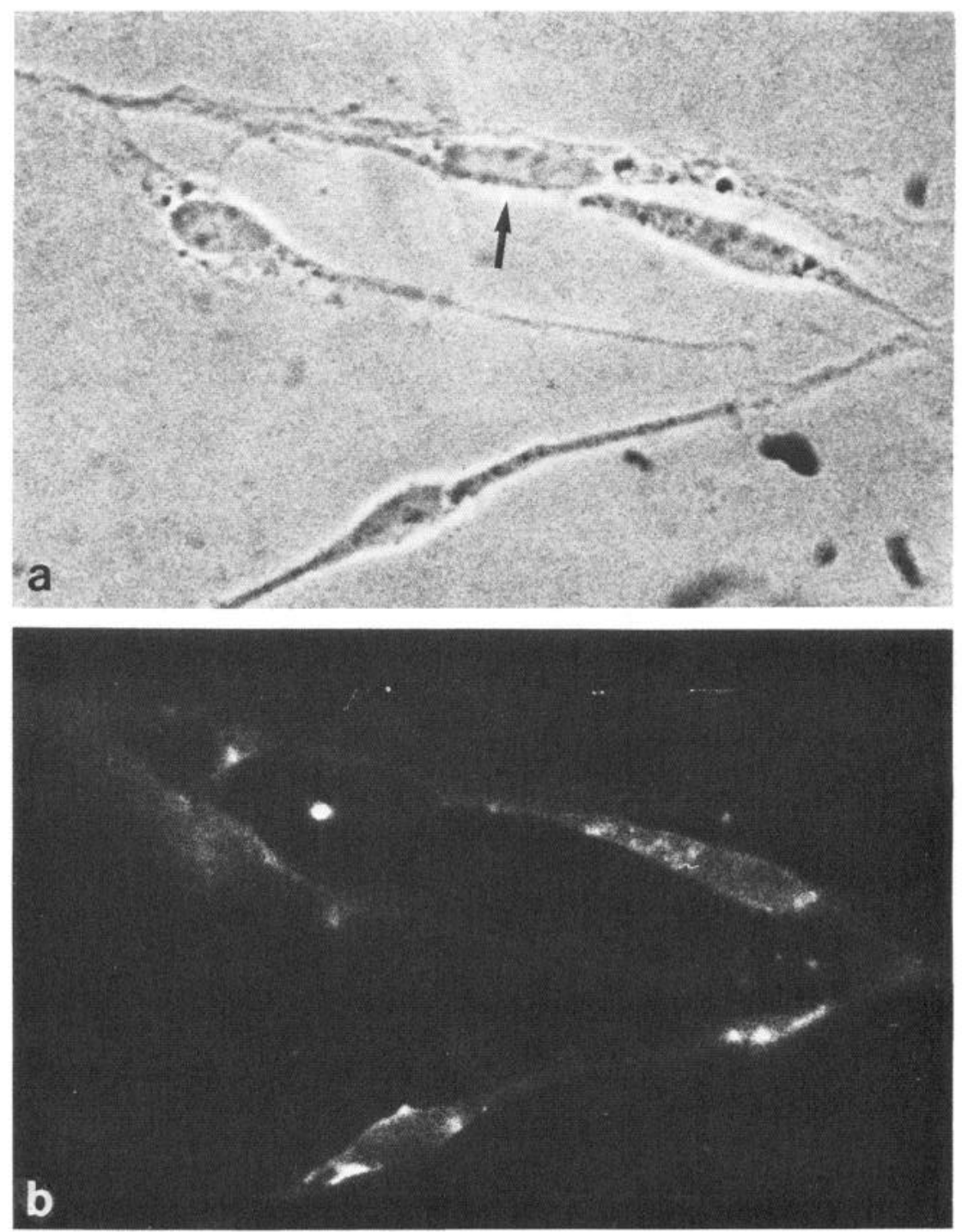

Figure 3. Culture of nerves of the brachial plexus from a quail-chick spinal cord chimera at E10 obtained as described in Materials and Methods. a, Phase-contrast of a $24 \mathrm{hr}$ culture showing elongated cells after nerve fiber degeneration. $b$, Immunostaining of the culture with GIN1 and GAM-FITC. One of the cells ( $a r$ row in $a$ ) does not react with the antibody. $c$, Staining of the nucleus with the Hoechst reagent: The nuclei of the 3 GIN1-positive cells (double arrows) show the large quail nucleolus, which is lacking from the nucleus of the GIN1-negative cell (single arrow). The former are Schwann cells derived from the grafted quail neural primordium; the latter is a chick fibroblast. $\times 1072$.

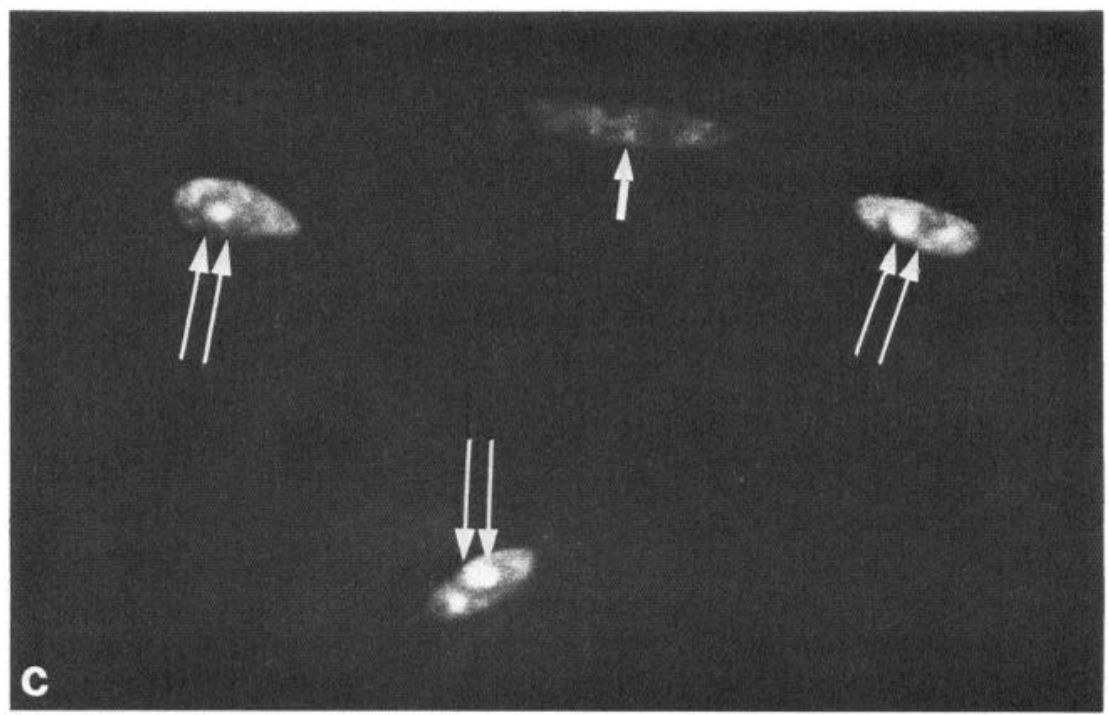

70 exhibited a surface immunoreactivity with GIN1, while nearly $70 \%$ of the cells devoid of NF-70 were positive with GIN1. In nodose and sympathetic ganglion cell suspensions, the percentage of neurons labeled by the MAb was significantly higher than in DRG. Quantitatively similar results were obtained (data not shown) in double-labeling experiments in which tetanus toxin binding was used to characterize the neuronal phenotype in DRG cell suspensions prior to treatment with GIN1. 

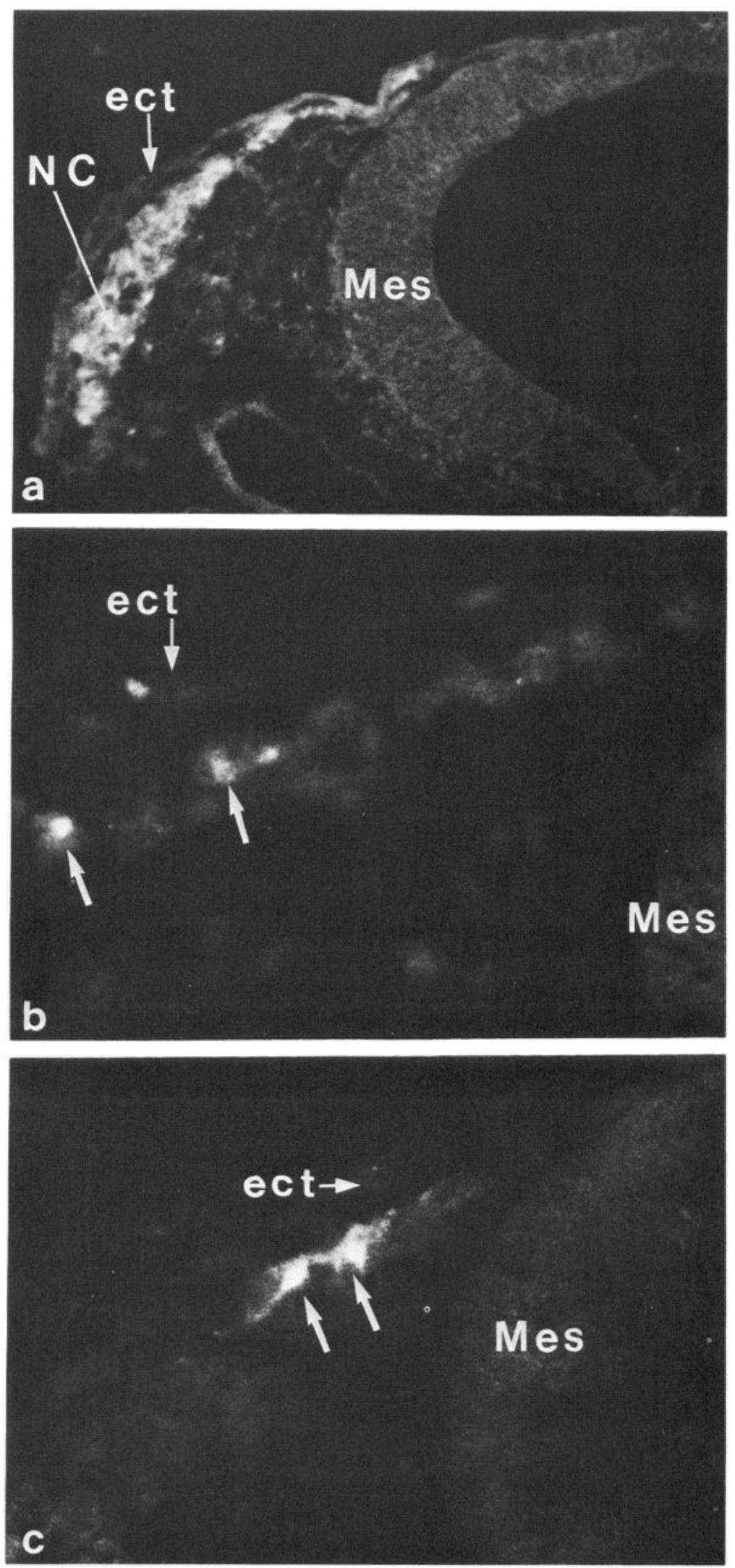

Figure 4. Transverse sections of quail embryos at the 12-somite stage showing the migrating mesencephalic neural crest $(N C)$ and the mesencephalon primordium (Mes). a, GIN2MAb stains most neural crest cells migrating underneath the superficial ectoderm $(e c t), \times 636 . b$ and $c$, Two axial levels of the embryo stained with GIN1 showing that a few cells only (arrows) stain in the migrating neural crest. $\times 895$.

GIN1 labeling of peripheral nerve Schwann cells was demonstrated by combining MAb immunocytochemistry with the quail-chick marker system. It has been previously demonstrated that the substitution of a fragment of quail neural primordium for its chick counterpart prior to neural crest cell migration in the chick host results in the derivation from the graft of all Schwann cells of the peripheral nerves located at the level of the implant. In contrast, the connective cells lining the nerve 

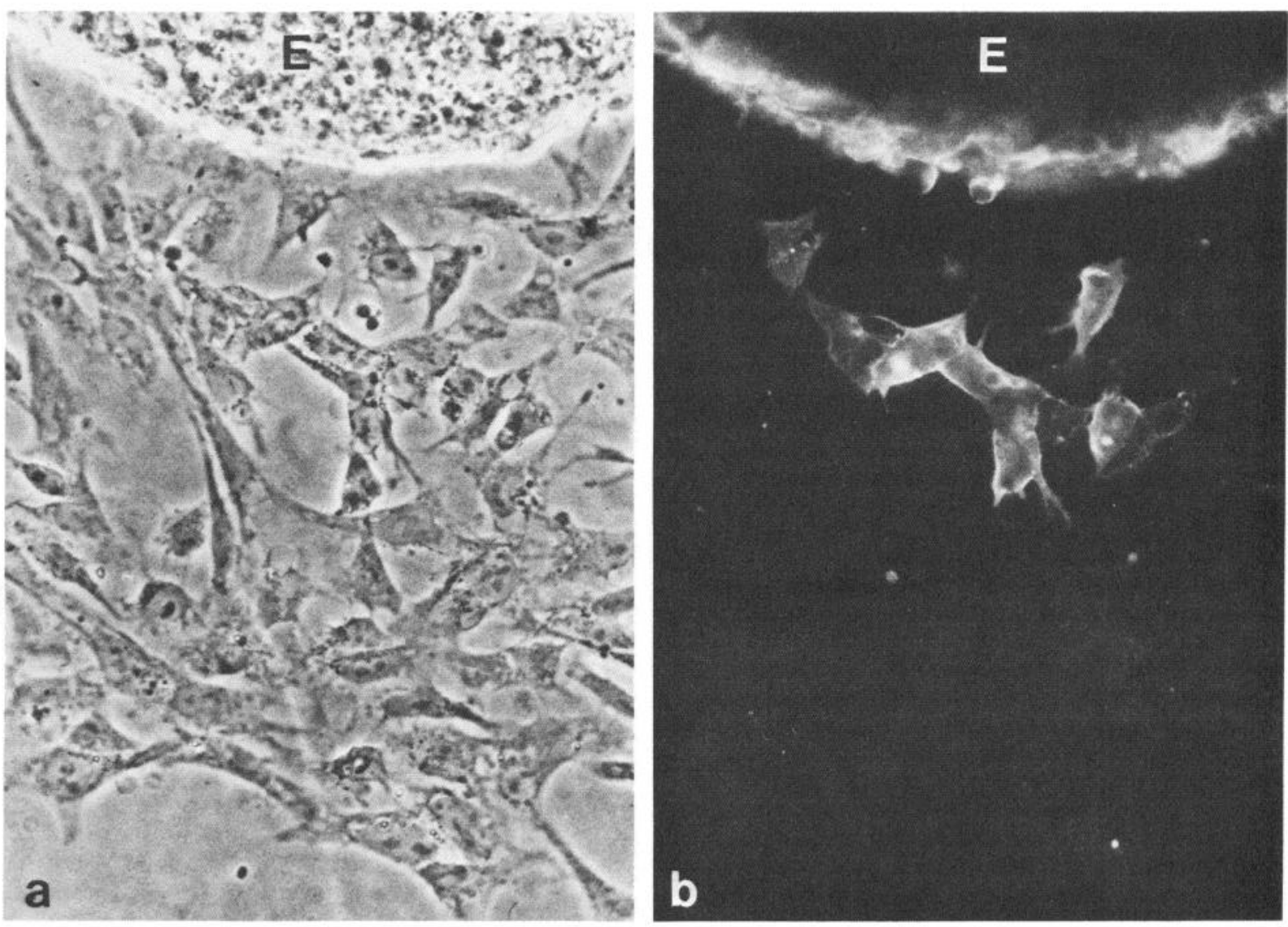

Figure 5. GIN1 immunostaining of 12-hr mesencephalic neural crest cultures. Explants of the migrating mesencephalic neural crest were removed together with the superficial ectoderm from 12-somite quail embryos. The neural crest cells have migrated away from the initial explant $(E)$. A few cells only are labeled with GIN1 - compare phase-contrast image (a) with GIN1 immunostaining $(b) . \times 403$.

belong to the chick host (see Le Douarin, 1982). As a result, when fragments of such nerves are cultured in vitro, Schwann cells and fibroblasts can be distinguished on the basis of the structure of their nucleus after DNA-specific staining. Accordingly, fragments of the brachial plexus from a quail-chick chimera were cultivated for $24 \mathrm{hr}$ and thereafter double-stained with GIN1 and Hoechst's reagent. Cells with the typical quail nucleus were found to react positively with the $\mathrm{MAb}$, while the fibroblasts exhibiting the chick-type nucleus did not (Fig. 3).

Cellular specificity for GIN1 was further investigated on sections of quail embryos at stages ranging from E2 to E14. Cells other than those of the PNS were also found to be recognized by the antibody. Thus, the CNS exhibited a faint immunoreactivity with the MAb from E3 onward, as did thymocytes toward the end of the incubation period in the thymic cortex. A more detailed investigation of the cross-reactivity of this antibody in the nervous and immune systems is currently in progress in our laboratory.

Apart from some transient immunoreactivity observed around the notochordal area, in the endocardial cushions, and in Rathke's pouch and pharyngeal epithelia at E3 to E5, GIN1 did not stain any other cell type in the embryo.

In a subsequent step, we investigated the ontogenetic appearance on the cells of the PNS of the antigenic determinant defined by this antibody.

\section{Appearance of antigen(s) recognized by GlN1 on neural crest cells}

In situ the first cells of the embryo to react with the antibody were situated at the level of the cephalic neural crest. The im- munoreactivity progressively appeared, according to a craniocaudal gradient, on trunk neural crest as it started to migrate. In no case did we find labeled crest cells in the neural fold prior to migration. Only a small percentage of crest cells stained with GIN1, irrespective of the level of the neuraxis considered (Fig. $4, b, c)$. For comparison, a section through the mesencephalic region was stained with another MAb, GIN2, which labeled the majority of migrating crest cells under our assay conditions (Fig. $4 a)$.

The percentage of immunoreactive neural crest cells was evaluated in cell suspensions and in short-term cultures. In suspensions of mesencephalic crest ceils removed from 12-somite-stage quail embryos, approximately $28 \%$ of the cells were labeled with GIN1. A similar percentage of crest cells was stained with GIN1 in short-term cultures of mesencephalic (Fig. 5) and trunk neural crest.

Quantitation was also performed in situ. For greater precision in identifying the migrating neural crest cell population, chimeric embryos were constructed. The mesencephalic neural primordium (including the neural fold) or the neural fold itself taken from a quail embryo was grafted isotopically at the 5- to 6 -somite stage into a chick. When migrating a few hours later (at the 12-somite stage), the neural crest cells could then be precisely distinguished from mesodermal cells on the basis of their nuclear structure (Fig. 6). Serial sections $(7 \mu \mathrm{m})$ were cut through the heads of 2 such chimeric embryos. Cell counts performed on 5 or 7 sections in the mesencephalic areas revealed that in 1 embryo, 41 of 162 quail cells exhibited GIN1 immunofluorescence (about 25\%); in the other embryo, 44 out of 139 quail cells were GIN1-positive (32\%). 

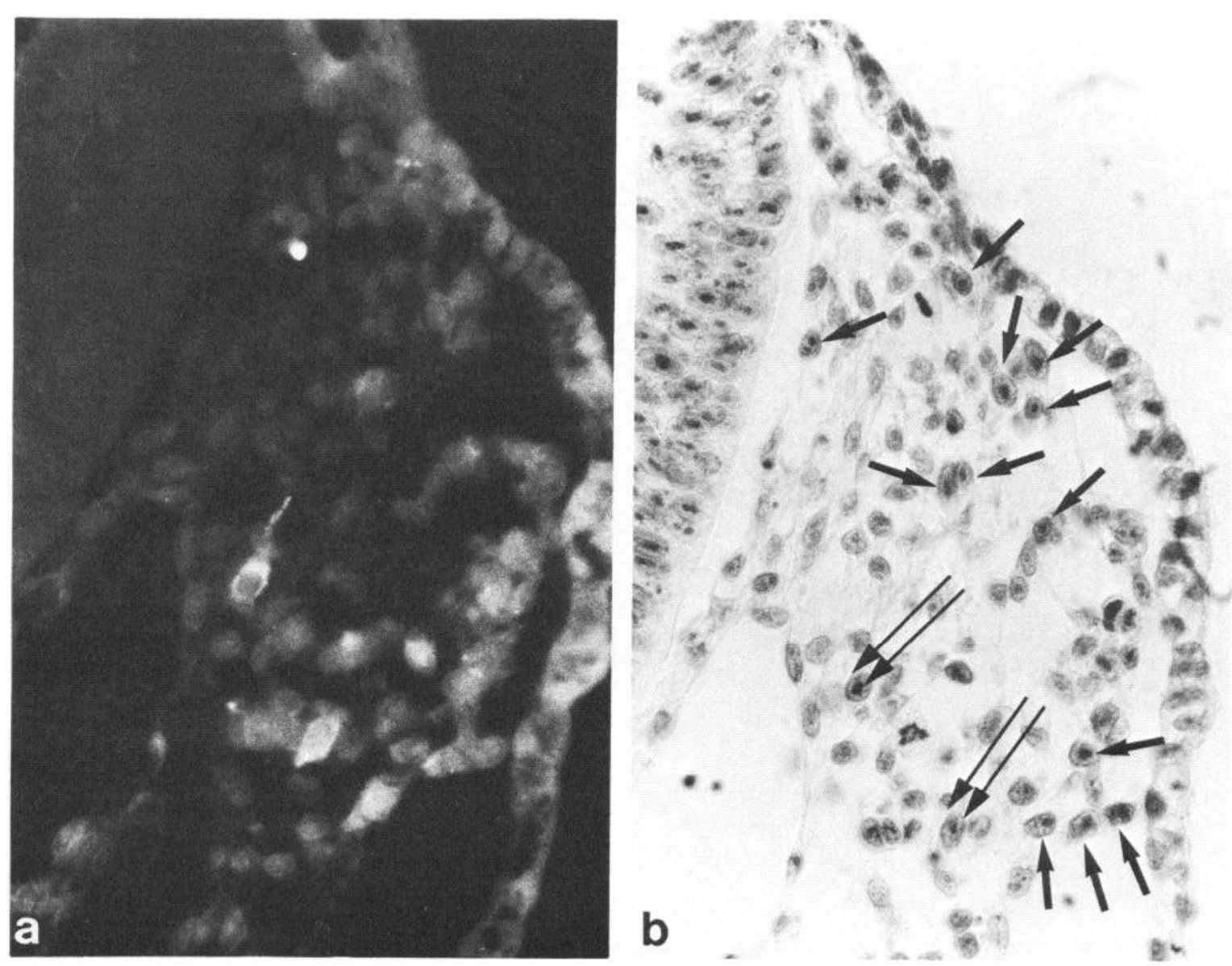

Figure 6. GIN1-immunostaining of migrating neural crest cells labeled by the quail marker in a quail-chick neural tube chimera (see Materials and Methods). The section is at the level of the anterior metencephalon in a 13-somite chimeric embryo. Immunoreactive quail cells are indicated in $b$ by double arrows and nonimmunoreactive quail cells by single arrows. $a$, GIN1 and GAM-FITC. $b$, Feulgen-Rossenbeck staining of the same section after postfixation with Zenker's fluid. $\times 636$.

\section{GlN1 antigen(s) on developing ganglia in situ}

The immunoreactivity observed in the migrating neural crest with GIN1 persisted throughout development and into adulthood in all the neural structures derived from it (ganglia, nerves, and plexuses).

For example, immunostaining with the antibody at the cephalic level allowed the early steps of development of the cranial peripheral ganglia to be precisely followed. The sensory ganglia of the head arise along a craniocaudal gradient, and, at the 22-somite stage, the first aggregates from which the proximal part of the trigeminal ganglia develops were already conspicuously stained, while formation of the distal portion of trigeminal ganglia from both neural crest and trigeminal placode was in progress. Crest cells migrating toward the trigeminal placode were immunostained with GIN1 (Fig. 7).

Subsequently (between the 25 - and 35 -somite stages), the progressive craniocaudal formation of the other sensory cephalic ganglia (i.e., the vestibuloacoustic and geniculate, the jugularsuperior complex, the petrosal and the nodose ganglia) takes place. All appeared brightly stained, although immunoreaction was restricted to a minor cell population (Fig. 8).

Similar results were obtained with dorsal root, sympathetic, and enteric ganglia and plexuses, which showed constant immunoreactivity during and after their formation.

In adult DRG and nodose ganglia, the satellite cells were brightly stained and some neurons were clearly immunoreactive (Fig. 9). The percentage of positive neurons was esssentially the same as in E15 ganglia.

Although most experiments were done with quail cells and tissues, immunostaining performed on chick neural crest and peripheral ganglion cells gave similar results.

Preliminary characterization of the antigen(s) recognized by GINI Membrane extracts were prepared from E12 quail DRG cultures that had been biosynthetically labeled with ${ }^{35} \mathrm{~S}$-methionine. GIN1 immunoprecipitated products that, in SDS-PAGE, appeared as 2 closely associated bands with an apparent molecular weight around $80,000 \mathrm{Da}$. An irrelevant IgM MAb, anti-MB1, did not recognize this molecule under similar conditions (Fig. 10).

\section{Conclusions and Discussion}

Our specific aim in this study was to identify surface markers characteristic of particular subsets of PNS ganglion cells and to study their expression in neural crest cells. GIN1, described here, recognizes an antigenic determinant present in virtually all the satellite cells of the peripheral ganglia, all Schwann cells of the embryonic peripheral nerves, and certain sensory and autonomic neurons in embryos and adults of both quail and chick species.

Moreover, GIN1 determinant is already present on neural crest cells as soon as they leave the neural primordium. The 
Figure 7. Transverse section of a 30somite quail embryo at the metencephalic level immunostained with GIN1-MAb. GIN1-negative trigeminal placodal cells $(P l)$ are visible in the placodal ectoderm and migrating away from it $(m P l)$. Many GIN1-positive cells, probably of neural crest origin, are seen (arrows). $\times 445$.

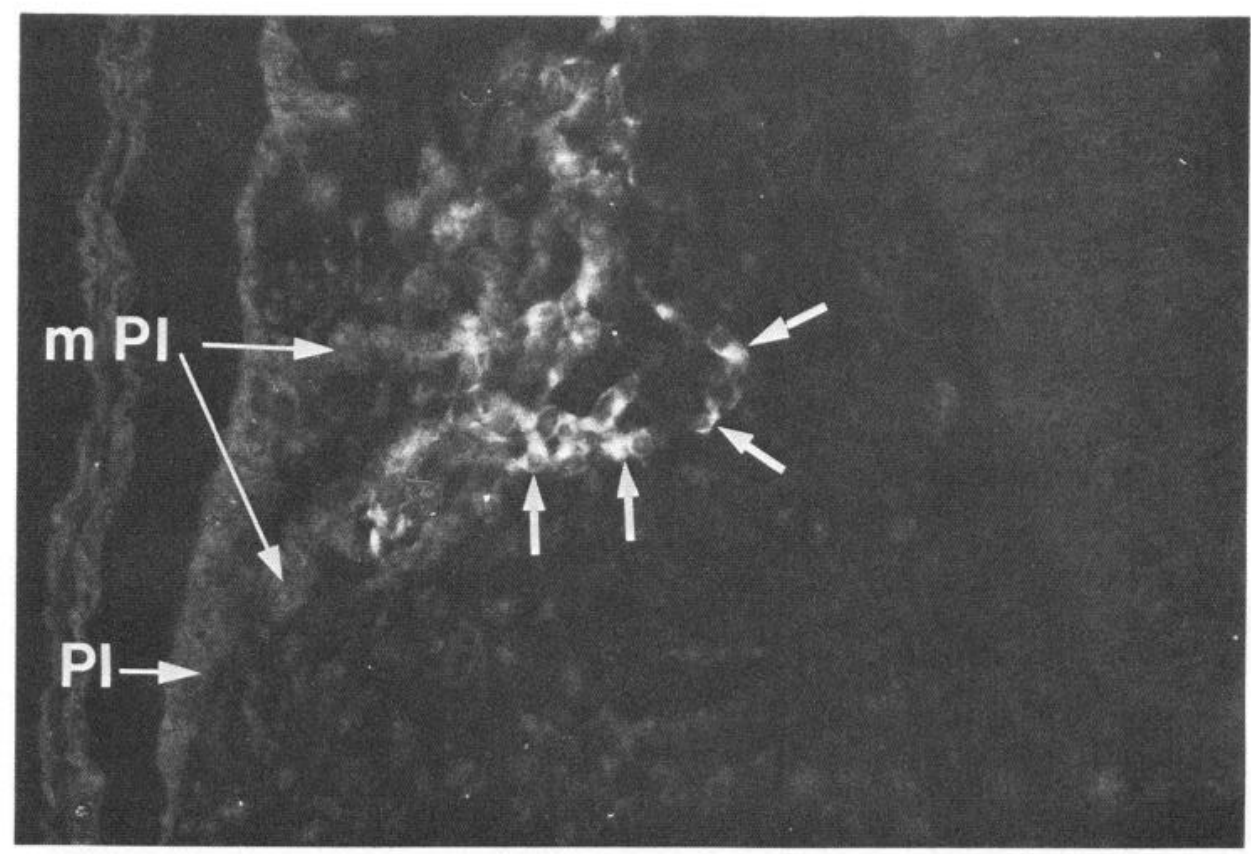

expression of the antigenic molecule is not a property of the entire crest cell population but concerns only a minor proportion (about 25\%). From the staining pattern observed at later developmental stages, it can be inferred that GIN1 is a lineage marker that characterizes precursors of glial cells and subpopulations of neurons in the neural crest.

The antigenic determinant detected by GIN1 on E12 quail DRG cultures is present on a molecule of $80 \mathrm{kDa}$ molecular weight. In fact, as shown in Figure 10, GIN1 recognizes 2 bands that migrate very close together. We do not yet know if this doublet represents the degradation products of a single parent molecule, or if it corresponds to 2 distinct molecular entities with slightly variant protein or carbohydrate moieties. In the latter case, it would clearly be of interest to determine whether both molecules are present in all GIN1-positive cells or whether each is restricted to a particular cell type. Since the biochemical investigations exclusively concerned embryonic ganglia taken around midincubation, it is not known whether developmental changes occur in these molecules. Although their polypeptide nature can be deduced from the biochemical procedure used, it has not yet been ascertained whether they are glycosylated and, if so, whether the antibody is directed against the glycosyl or peptide moiety.

This study reveals that the neural crest is composed of a heterogeneous population of cells that differentially express the antigenic determinant recognized by GIN1 as soon as crest cells begin to emigrate from the neural primordium.

Monoclonal antibody technology has already been applied to the problems raised by the differentiation of neural crest cells. In particular, Weston and coworkers have identified cell-type

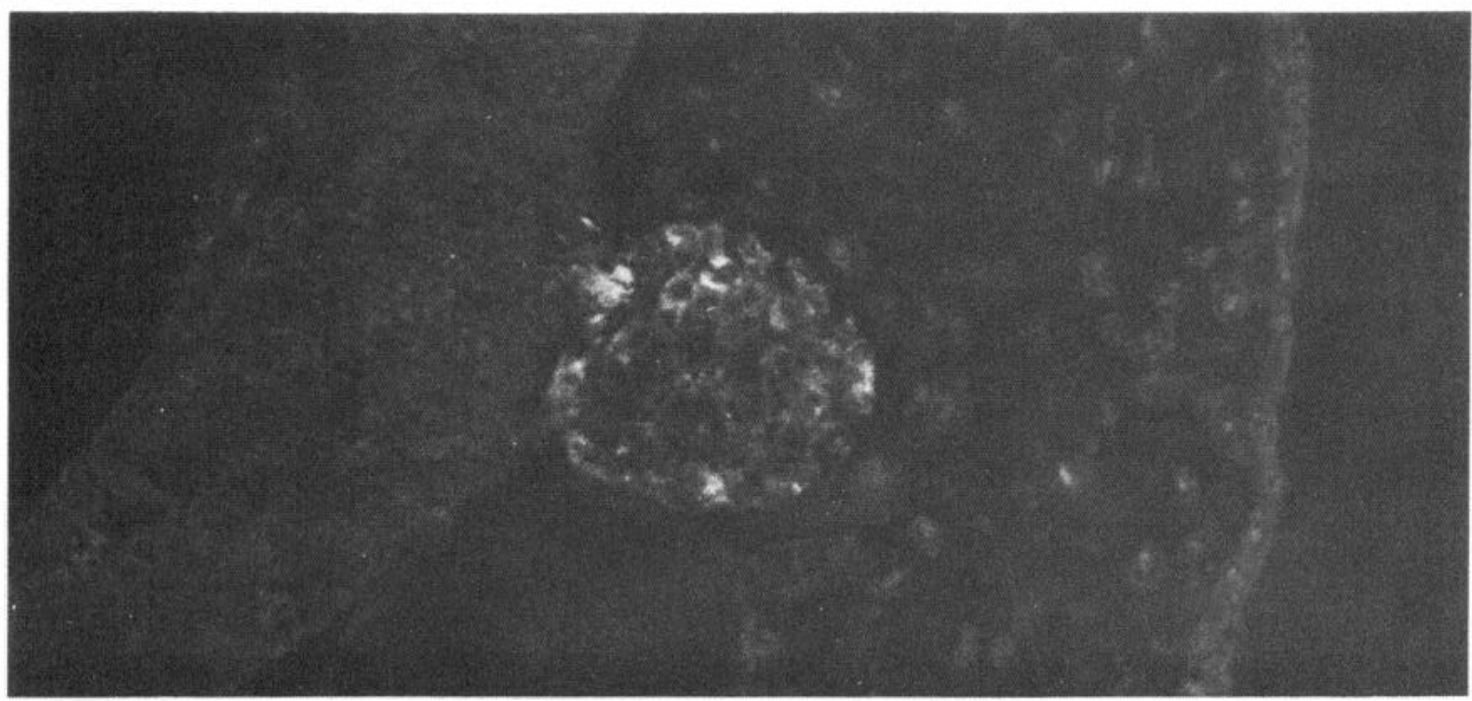

Figure 8. GIN1 staining in a developing cranial sensory ganglion. The section is cut through the proximal ganglion of the VIIth cranial nerve at the 30-somite stage. The ganglion, which is derived from the neural crest, will later fuse with the vestibular-acoustic complex (see D'Amico-Martel and Noden, 1983). Note that GIN1 stains a minority of the ganglion cells. $\times 530$. 

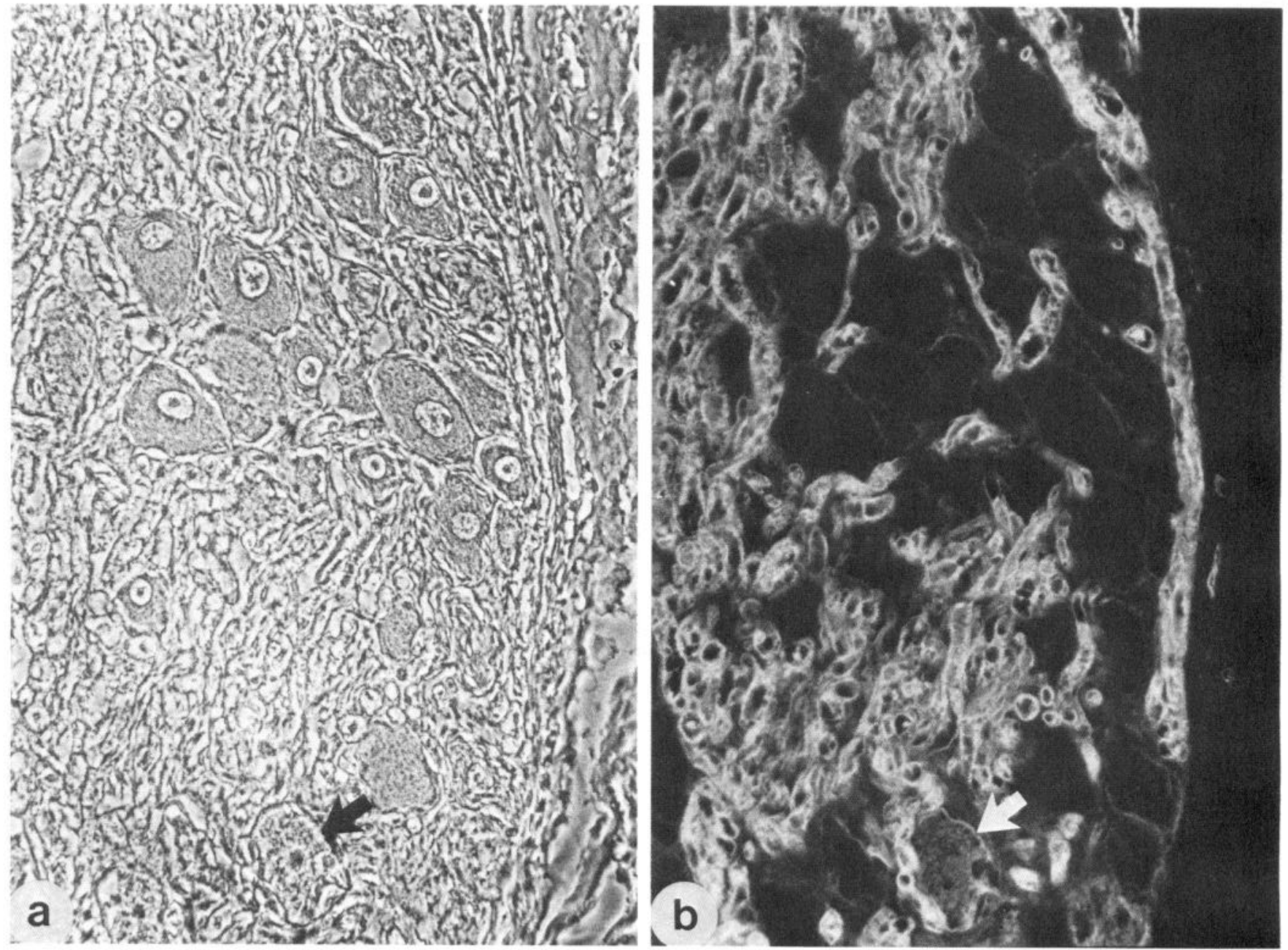

Figure 9. GIN1 immunoreactivity on a section through a 5-month quail nodose ganglion. $a$, Phase-contrast view (b) after staining with GIN1. Note that the glial cells are strongly labeled. A single immunoreactive neuron (arrow) can be seen. $\times 402$.

markers that appear early in neural crest cell ontogeny. These are $\mathrm{SN} 1$, which recognizes a subpopulation of sensory neurons (Marusich et al., 1985), but not neural crest cells, and EC8, which identifies a cytoplasmic polypeptide associated mainly with the neuronal phenotype but also with other cells in heart and limb bud. In the neural crest, EC8 appears at the end of neural crest cell migration (Ciment and Weston, 1982). Another indication of early diversification in the neural crest is the existence of neurofilament immunoreactivity in a few premigratory and early migratory crest cells of the chick (Payette et al., 1984). These findings suggest that a progressive commitment of neuronal precursors occurs during the migratory phase. Similar conclusions were drawn by means of a totally different experimental approach involving cultured cephalic and trunk neural crest, in which the expression of the neuronal phenotype was triggered within a few hours in a noncycling cell subpopulation by manipulating the culture conditions (Ziller et al., 1983). Further experiments along these lines have recently shown that, apart from these neuronal precursors that can extend neurites in culture without dividing, other progenitors differentiate into neurons displaying various autonomic phenotypes if they are provided with conditions allowing them to proliferate (Maxwell and Sietz, 1985; C. Ziller, M. Fauquet, J. Smith, and N. M. Le Douarin, unpublished observations, 1985).

Even more restricted in their cellular specificity were the an- tibodies CG1 and CG4 prepared in mouse by Barald (1982) after immunizing with chick ciliary ganglia. They were shown to stain only ciliary ganglion neurons and a small subpopulation of cultured mesencephalic neural crest cells. Their reaction with the crest in situ has not, however, been reported.

Antibodies such as A2B5, which recognizes a ganglioside in the GQ fraction (Eisenbarth et al., 1979), and R24, which recognizes the ganglioside $G_{D_{3}}$ (Puckel et al., 1982) although prepared from mammalian antigens, recognized identical structures in avian species. Their use on short-term quail neural crest cultures revealed a strikingly early diversity among the crest cell population (Girdlestone and Weston, 1985). Finally, acetylcholinesterase activity is not distributed uniformly throughout the neural crest: Although the great majority of crest cells display the enzymatic activity during migration, approximately $10 \%$ do not (Cochard and Coltey, 1983).

With regard to the in situ characterization of antigenic heterogeneity, GIN1 remains the reagent exhibiting the most striking picture. Moreover, its selective distribution on neural derivatives allows the antigenic determinant recognized by this MAb to be considered as a marker shared by glial cells, certain neurons, and their precursor cells of the neural crest. This characteristic can serve as a basis for further studies using clonal analysis of neural crest cells to decipher the pattern through which cell-line segregation takes place during PNS ontogeny. 
Figure 10. GIN1-immunoprecipitated ${ }^{35}$ S-methionine-labeled NP40 extracts of dissociated cell cultures of DRG from E12 quail after analysis by SDS-PAGE. The control precipitation was performed with an irrelevant IgM antibody (anti-MB1). Note the presence in the GIN1-precipitated material of a double band running at 80,000 . These bands are not present in the control.

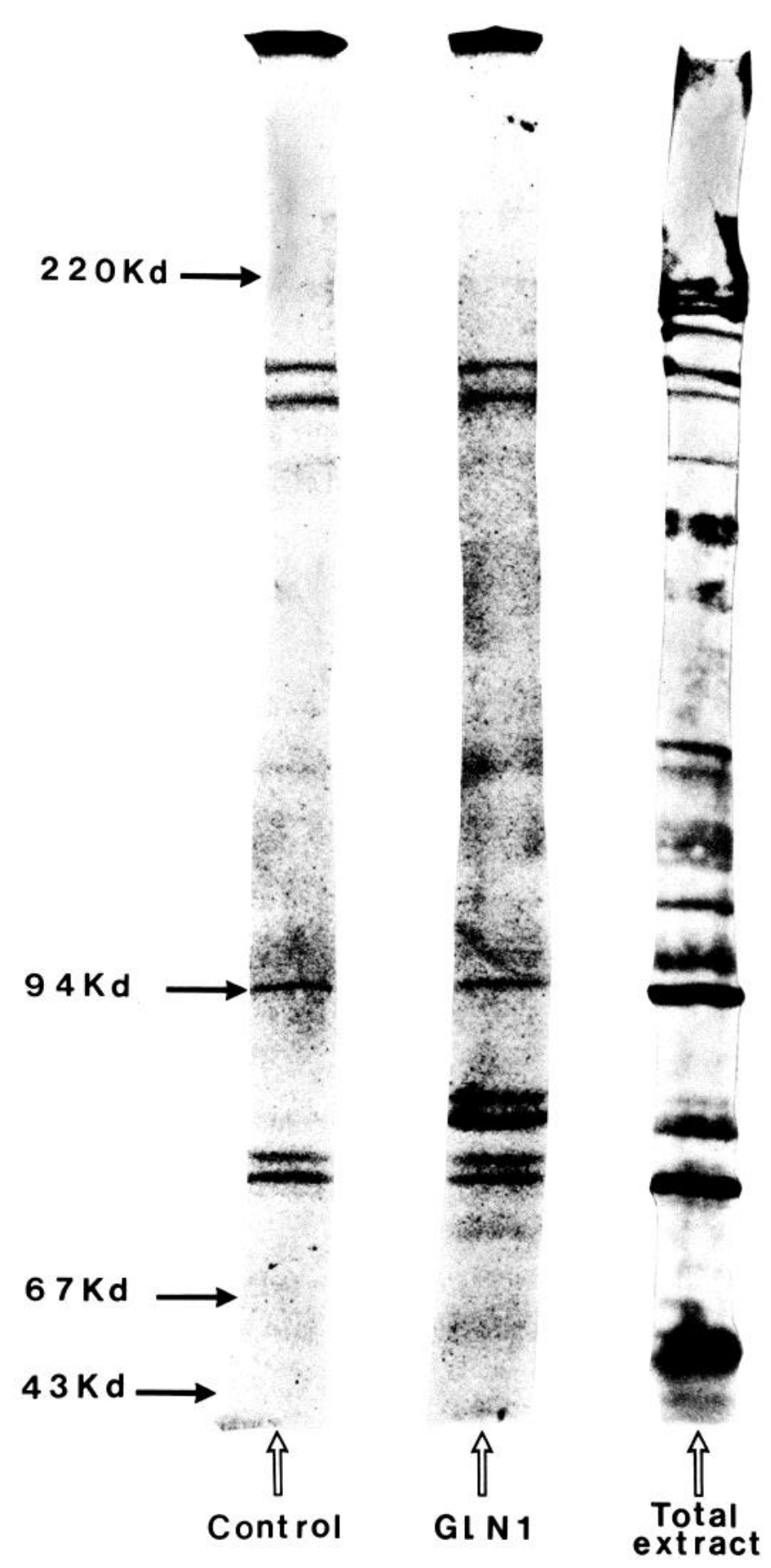

\section{References}

Abo, T., and C. M. Balch (1981) A differentiation antigen of human NK and $\mathrm{K}$ cells identified by a monoclonal antibody (HNK-1). J. Immunol. 127: 1024-1029.

Barald, K. F. (1982) Monoclonal antibodies to embryonic neurons. Cell-specific markers for chick ciliary ganglion. In Neuronal Development, N. C. Spitzer, ed., pp. 101-119, Plenum, New York.

Charron, D. J., and H. O. Mc Devitt (1980) Characterization of HLA-D region antigens by two-dimensional gel electrophoresis. Molecular genotyping. J. Exp. Med. 158: 18s.

Ciment, G., and J. A. Weston (1982) Early appearance in neural crest and crest-derived cells of an antigenic determinant present in avian neurons. Dev. Biol. 93: 355-367.
Cochard, P., and P. Coltey (1983) Cholinergic traits in the neural crest: Acetylcholinesterase in crest cells of the chick embryo. Dev. Biol. 93: 221-238.

Cochard, P., and D. Paulin (1984) Initial expression of neurofilaments and vimentin in the central and peripheral nervous system of the mouse embryo in vivo. J. Neurosci. 4: 2080-2094.

Cochard, P., M. Goldstein, and I. B. Black (1978) Ontogenic appearance and disappearance of tyrosine hydroxylase and catecholamines in the rat embryo. Proc. Natl. Acad. Sci. USA 75: 2986-2990.

Cochard, P., M. Goldstein, and I. B. Black (1979) Initial development of the noradrenergic phenotype in autonomic neuroblasts of the rat embryo in vivo. Dev. Biol. 71: 100-114.

Cohen, A. M., and I. R. Konigsberg (1975) A clonal approach to the problem of neural crest determination. Dev. Biol. 46: 262-280. 
D'Amico-Martel, A., and D. M. Noden (1983) Contributions of placodal and neural crest cells to avian cranial peripheral ganglia. Am. J. Anat. 166: 445-468.

Eisenbarth, G. S., F. S. Walsh, and M. Nirenberg (1979) Monoclonal antibody to a plasma membrane antigen of neurons. Proc. Natl. Acad. Sci. USA 76: 4913-4917.

Feulgen, R., and H. Rossenbeck (1924) Mikroskopisch-chemischer Nachweis einer Nucleinsaüre vom Typus der Thymonucleinsaüre und die darauf beruhende elektive Färbung von Zellkernen in mikroskopischen Präparaten. Hoppe Seylers Z. Physiol. Chem. 135: 203248.

Franklin, R. M., and M. T. Martin (1980) Staining and histochemistry of undecalcified bone embedded in a water-miscible plastic. Stain Technol. 55: 313-321.

Girdlestone, J., and J. A. Weston (1985) Identification of early neuronal subpopulations in avian neural crest cultures. Dev. Biol. 109. 274-287.

Köhler, G., and C. Milstein (1975) Continuous cultures of fused cells secreting antibody of predetermined specificity, Nature 256:495-497.

Laemmli, U. K. (1970) Cleavage of ultrastructural proteins during the assembly of the head of bacteriophage T4. Nature 227: 680-685.

Le Douarin, N. (1982) The Neural Crest, Cambridge U. P., Cambridge, UK.

Le Douarin, N. (1984) A model for cell-line divergence in the ontogeny of the peripheral nervous system. In Cellular and Molecular Biology of Neuronal Development, I. B. Black, ed., pp. 3-28, Plenum, New York

Marusich, M. F., K. Pourmehr, and J. A. Weston (1985) Subpopulations of neural crest cells and non-neuronal dorsal root ganglion cells express a sensory neuron specific epitope. Cell Differ. 16 (Suppl. 273): 113 s.
Maxwell, G. D., and P. D. Sietz (1985) Development of cells containing catecholamines and somatostatin-like immunoreactivity in neural crest cultures: Relationship of DNA synthesis to phenotypic expression. Dev. Biol. 108: 203-209.

Payette, R. F., G. S. Bennet and M. D. Gershon (1984) Neurofilament expression in vagal neural crest derived precursors of enteric neurons. Dev. Biol. 105: 273-287.

Péault, B. M., J. P. Thiery, and N. M. Le Douarin (1983) Surface marker for hemopoietic and endothelial cell lineages in quail that is defined by a monoclonal antibody. Proc. Natl. Acad. Sci. USA 80. 2976-2980.

Puckel, C. S., K. O. Lloyd, L. R. Travassos, W. G. Dippold, H. H. Oettgen, and L. J. Old (1982) $\mathrm{G}_{\mathrm{D} 3}$, a prominent ganglioside of human melanoma. Detection and characterization by mouse monoclonal antibody. J. Exp. Med. 155: 1133-1147.

Tucker, G. C., H. Aoyama, M. Lipinski, T. Tursz, and J. P. Thiery (1984) Identical reactivity of monoclonal antibodies HNK-1 and $\mathrm{NC}-1$ : Conservation in vertebrates on cells derived from the neural primordium and on some leukocytes. Cell Differ. 14: 223-230.

Vincent, M., and J. P. Thiery (1984) A cell surface marker for neural crest and placodal cells: Further evolution in peripheral and central nervous system. Dev. Biol. 103: 468-481.

Weston, J. A. (1982) Motile and social behaviour of neural crest cells. In Cell Behaviour, R. Bellairs, A. Curtis, and G. Dunn, eds., pp. 429 469, Cambridge U. P., Cambridge, UK.

Ziller, C., E. Dupin, P. Brazeau, D. Paulin, and N. M. Le Douarin (1983) Early segregation of a neuronal precursor cell line in the neural crest as revealed by culture in a chemically defined medium. Cell 32 : 627-638. 